\title{
Effect of Job Stress and Organizational Climate on Turnover Intention with Job Satisfaction as an Intervening Variable for Employees of STMIK STIE Mikroskil
}

\author{
Purnaya Sari Tarigan', Paham Ginting ${ }^{2}$, Elisabet Siahaan ${ }^{2}$ \\ ${ }^{1}$ Postgraduate Students, Department of Management, Faculty of Economics and Business at Universitas \\ Sumatera Utara, Indonesia \\ ${ }^{2}$ Postgraduate Lecturer, Department of Management, Faculty of Economics and Business at Universitas \\ Sumatera Utara, Indonesia
}

Corresponding Author: Purnaya Sari Tarigan

\begin{abstract}
This study aims to determine the effect of job stress and organizational climate on turnover intention. In addition, this study also tries to prove whether job satisfaction can be used as an intervening variable in the research model. This type of research is a qualitative descriptive study. This research was conducted on the employees of STMIK STIE Mikroskil. The sample selection using proportional random sampling technique shows that the research sample is 95 people. The data analysis method used in this research is path analysis which is carried out with the help of SPSS software. The results showed that job stress and organizational climate have a positive and significant effect on employee job satisfaction at STMIK STIE Mikroskil. Job stress has no effect on turnover intention, while organizational climate has a positive and significant effect on turnover intention. Job satisfaction has no effect on turnover intention. Meanwhile, the intervening variable, namely job satisfaction, is not able to interview the effect of job stress and organizational climate on turnover intention of STMIK STIE Mikroskil employees.
\end{abstract}

Keywords: Job Stress, Organizational Climate, Job Satisfaction, Turnover Intention

\section{INTRODUCTION}

Rapid environmental changes, which are marked by advances in information, changes in market tastes, changes in demographics, economic fluctuations, and other dynamic conditions, require organizations to respond to changes in order to survive in global competition. Organizations often have to change their organizational structure and form so that they can respond to changes that occur. These organizational changes will have an impact on every individual in the organization. Every individual who is part of an organization is required to develop and realize their full competence. The organization will take advantage of the competencies possessed by individuals by developing opportunities for each individual to develop their careers.

Changes in organizational environmental conditions, both internal and external, encourage organizations to respond quickly and adapt to a competitive market environment. Organizations must be more flexible to adapt to an increasingly competitive environment. Organizational flexibility is determined by resources that have high abilities and skills that make the organization have a competitive advantage so that it can win the competition.

The performance of a company is determined by the conditions and behaviors of human resources, in this case the employees of the company. The 
phenomenon that often occurs is that the performance of a company that has been so good can be disrupted, either directly or indirectly, by various employee behaviors that are difficult to prevent from occurring. One form of employee behavior is the desire to quit which leads to the employee's decision to leave his job (Winterton, 2014). In relation to human resources, from the various studies that have been carried out, changes in organizational environmental conditions both internally and externally can directly or indirectly affect the organizational climate and employee stress levels which can reduce the level of job satisfaction which in turn can lead to the intention to quit employee which in turn can lead to actual quit.

Employees are not managed properly, so employees will be less enthusiastic at work and eventually resign or leave the workplace (turnover intention). Employee turnover intention is one of the main problems faced by organizations without considering the location, size, nature of the business and business strategy (profit or non-profit). Hartono in Robbins and Judge (2010) states that turnover intention is the intensity level of the desire to leave the company.

According to Griffet in Handoko (2014) that almost all turnover intention models are due to low levels of job satisfaction and organizational commitment, namely job satisfaction is closely related to the cognitive process of withdrawing (pre with drawal cognition), the intention to leave and real action in the form of decisions. To leave the workplace and commitment to the organization are the factors that most influence the occurrence of turnover intention compared to job satisfaction. Currently employees not only expect rewards for services provided to the organization, but also employees seek recognition, rewards, policies that affect their work and career, cooperative colleagues and fair compensation. Therefore, if these demands are not fulfilled by the company, it will allow employee turnover.

Sekolah Tinggi Manajemen Informatika dan Komputer (STMIK) Sekolah Tinggi Ilmu Ekonomi (STIE) Mikroskil is a private university in Medan City, North Sumatra, which emphasizes on information technology. Yayasan Bina Pertiwi established the Sekolah Tinggi Manajemen Informatika dan Komputer (STMIK) Sekolah Tinggi Ilmu Ekonomi (STIE) Mikroskil in 1997.

In the data, the number of STMIK STIE Mikroskil employees has increased every year, in 2016 there were 93 people, consisting of 46 academic employees and 47 non-academic employees. In 2017, there were 110 people, consisting of 56 academic employees and 54 non-academic employees. Meanwhile, in 2018 there were 124 people, consisting of 58 academic employees and 66 non-academic employees.

The high turnover intention at STMIK STIE Mikroskil can be caused by several factors. According to Kaswan (2012) that organizational commitment and job satisfaction are predictors of turnover intention. Another study conducted by Mondy (2010) indicates that job satisfaction and organizational commitment have the greatest influence on turnover intention. In connection with the emergence of turnover intention, employees who have job satisfaction will be more productive, contribute to the goals and objectives of the organization, and generally have a low desire to leave the company. Worker dissatisfaction can lead to unwanted work results such as theft, looking for odd jobs and can lead to absenteeism (Samad, 2014). Employee dissatisfaction also tends to lead to behavioral practices of withdrawal from work such as leaving the company or resigning and considering other job opportunities (Samad, 2014).

Mobley (2012:44) reveals that turnover intention is marked by the intention to leave the organization and the desire to find alternative jobs that are better than the previous organization. The following is the 
identification of the phenomenon of turnover intention at STMIK STIE Mikroskill based on a pre-survey conducted by researchers on January 8, 2019 at STMIK STIE Mikroskill.

The high level of employee turnover intention is a measure that is often used as an indication of an underlying problem in the organization. Employee turnover intention can create instability and uncertainty about employee conditions, as well as increase recruitment costs. Therefore, a company is required to be able to retain its employees, such as being able to provide high remuneration and understanding things that can make employees feel at home to continue working without reducing the company's overall performance.

One of the various factors that need the company's attention to reduce employee turnover intention is how the company manages a good and conducive climate for employee work activities and efforts to manage good and sustainable human resources to reduce stress levels that can be experienced by employees.

Performance that does not reach the target is an indicator of employee work stress caused by working hours that are not in accordance with the workload, causing fatigue and consequently employees cannot work optimally (Samad, 2014). Therefore, working hours must be implemented effectively so that employees do not experience work stress. According to Pencavel (2015), the ideal working time is 7-8 hours per day which aims to optimize worker productivity while working. Employee working hours at STMIK STIE Mikroskil are for Monday to Friday (type 3) for 8 hours of employee work starting from 08.30 to 16.30 , while for Saturdays it starts at 08.30 to 14.30 with a total working hours of 6 hours.

From the results of the pre-research survey conducted, almost $>50 \%$ of respondents agreed to the questions asked to assess the level of work stress they experienced at STMIK STIE Mikroskil, this proved that there were indications that employees experienced very high work stress at STMIK STIE Mikroskil. In this study, respondents said that the cause of work stress occurs in which an uncomfortable work environment will make someone feel depressed so that it causes stress on employees and a large workload that makes employees feel depressed, causing increased work stress. The results of research conducted by (Waspodo, 2013) stated that job stress has a significant positive effect on employee turnover intention.

This study aims to determine the effect of job stress and organizational climate on turnover intention. In addition, this study also tries to prove whether job satisfaction can be used as an intervening variable in the research model.

\section{RESEARCH METHODS}

This type of research is a qualitative descriptive study. Quantitative descriptive research is research that aims to describe or describe the properties (characteristics) of a state or research object that has been mentioned. The results are then presented in the form of research. This research was conducted on the employees of STMIK STIE Mikroskil.

Population is a generalization area consisting of objects or subjects that have certain qualities and characteristics that are determined by researchers to study and then draw conclusions (Sugiyono, 2016:215). The population in this study were employees of STMIK STIE Mikroskil. The total number of employees is 124. The largest number of employees are nonacademic employees, namely 66 people, while the number of academic employees is 58 people.

The data analysis method used in this research is path analysis which is carried out with the help of SPSS software. 


\section{RESULT}

\section{General Description}

History begins in 1992, when the Yayasan Bina Pertiwi Medan established a computer education course under the name IMC. IMC at that time held computer training/courses with a period of 3,4 , and 6 months. With satisfying services and supported by quality human resources, IMC is well known and in demand by the people of North Sumatra so that this institution is growing rapidly.

Seeing the great interest of the people of North Sumatra, especially the people of Medan City to receive training at IMC and supported by the rapid development of information technology, on March 20, 1994 IMC was upgraded to a Diploma 1 (D-1) education program with the name Microskills. Microskills collaborates with Microskills Singapore, the National Computing Center (NCC) and the London Chamber of Commerce and Industry (LCCI) United Kingdom, in the fields of computer science education, accounting, management, taxation, and secretarial affairs. The existence of Microskills has received quite a lot of response and support from people who are interested in exploring information technology. This can be seen from the increase in the number of students from year to year and the demand for Microskills graduate workforce from companies.

A positive response to Microskills encourages the leadership of Microskills and Yayasan Bina Pertiwi Medan to reupgrade this educational institution into a high school. On August 1, 1997, Microskills was upgraded to the Sekolah Tinggi Manajemen Informatika dan Komputer (STMIK) Mikroskil with the Decree of the Minister of Education and Culture No.45/D/O/1997.

Initially, STMIK Mikroskil opened an undergraduate program (S-1) in Informatics Engineering and a diploma program 3 (D-3) in Information Management and Computerized Accounting, in addition to the pre-existing
D-1 program. In 2000, STMIK Mikroskil opened an undergraduate program (S-1) Information Systems. In an effort to improve the quality and at the same time as a benchmark for education that has been implemented, in 2002, STMIK Mikroskil applied for accreditation to the National Accreditation Board for Higher Education (BAN-PT), and in that year all Departments/Study Programs were "Accredited".

Achievements for the sake of achievement were achieved by STMIK Mikroskil, both in the academic and nonacademic fields at the local, provincial, national, and ASEAN levels. Armed with achievements, experience, and many proposals from the business community for Mikroskil graduates in the economic field, the Bina Pertiwi Medan Foundation in 2008 established a new college, namely the Mikroskil College of Economics (STIE). In 2013, STIE Mikroskil carried out accreditation to BAN-PT for all existing study programs, and in that year all existing study programs were "Accredited". It is not easy to be complacent and realize that quality improvement and benchmarks must always be carried out consistently, so STMIK and STIE Mikroskil always carry out Re-Accreditation to BAN-PT for study programs whose Accreditation Certificate validity period will end soon. Institutional accreditation was also carried out by STMIK Mikroskil in 2015, and as a result, STMIK Mikroskil was declared "Accredited" at the Institutional level by BAN-PT based on decision No.0576/SK/BAN-PT/Akred/PT/V/2016 with a rating of "B ". Then in 2017, STIE Mikroskil achieved institutional accreditation from BAN-PT based on decision No.4044/SK/BANPT/Akred/PT/X/2017 with "B" rating.

\section{Respondent Description}

The sex of the most respondents was male, 45 respondents or 47.3 percent. Meanwhile, for respondents who were 
Purnaya Sari Tarigan et.al. Effect of job stress and organizational climate on turnover intention with job satisfaction as an intervening variable for employees of STMIK STIE Mikroskil.

female as many as 50 respondents or 52.7 percent.

Based on the data, it can be seen that respondents who have an age $\geq 41$ years are the least respondents with the number of respondents as many as 19 respondents or 20 percent while those who have the age 3035 years have the most respondents as many as 33 respondents or 34.7 percent of respondents.

Based on the data, it can be seen that respondents who have high school/vocational education are the least respondents with 16 respondents or 16.8 percent while those who have S2/S3 education have the most respondents as many as 50 respondents or 52.6 percent of respondents.

\section{Path Analysis}

The path analysis model is used to analyze the pattern of relationships between variables in order to determine the direct or indirect effect of a set of independent variables on the dependent variable.

Based on the formulation of the problem and the research hypothesis, it can be seen that the causal relationship between variables by describing the correlation coefficient is the direct and indirect effect. This relationship involves independent variables, namely profitability and intrinsic value of the company, independent variables, namely capital structure and sales growth. Problems that have the characteristics of a causal relationship between variables and the existence of a correlation between the two variables, so the analysis technique that can be used is to use the path analysis estimation technique.

Table 1. Results of Substructure Regression I

\begin{tabular}{|c|c|c|c|c|c|c|}
\hline \multicolumn{7}{|c|}{ Coefficients $^{\mathrm{a}}$} \\
\hline \multirow{2}{*}{\multicolumn{2}{|c|}{ Model }} & \multicolumn{2}{|c|}{ Unstandardized Coefficients } & \multirow{2}{*}{$\begin{array}{l}\text { Standardized Coefficients } \\
\text { Beta }\end{array}$} & \multirow[t]{2}{*}{$\mathbf{t}$} & \multirow[t]{2}{*}{ Sig. } \\
\hline & & B & Std. Error & & & \\
\hline \multirow[t]{3}{*}{1} & (Constant) & 13.186 & 2.048 & & 6.438 & .000 \\
\hline & Job Stress & .278 & .054 & .427 & 5.107 & .000 \\
\hline & Organizational Climate & .183 & .039 & .397 & 4.753 & .000 \\
\hline
\end{tabular}

Table 2. Results of Substructure Regression II

\begin{tabular}{|c|c|c|c|c|c|c|}
\hline \multicolumn{7}{|c|}{ Coefficients $^{\mathbf{a}}$} \\
\hline \multirow{2}{*}{\multicolumn{2}{|c|}{ Model }} & \multicolumn{2}{|c|}{ Unstandardized Coefficients } & \multirow{2}{*}{$\begin{array}{l}\text { Standardized Coefficients } \\
\text { Beta }\end{array}$} & \multirow[t]{2}{*}{$\mathbf{T}$} & \multirow[t]{2}{*}{ Sig. } \\
\hline & & B & Std. Error & & & \\
\hline \multirow[t]{4}{*}{1} & (Constant) & 3.159 & 3.200 & & .987 & .326 \\
\hline & Job Stress & .053 & .080 & .052 & .661 & .510 \\
\hline & Organizational Climate & .535 & .056 & .746 & 9.586 & .000 \\
\hline & Job Satisfaction & -.013 & .135 & -.008 & -.094 & .925 \\
\hline
\end{tabular}

Source: Data Processed, 2021

Table 3. Effect between Research Variables

\begin{tabular}{|c|c|c|c|c|c|}
\hline \multicolumn{3}{|c|}{ Independent Variable } & \multicolumn{2}{|c|}{ Effect } & \multirow[b]{2}{*}{ Total } \\
\hline Independent & Dependent & Intervening & Direct & Indirect & \\
\hline $\mathbf{X}_{1}$ & \multirow{2}{*}{$Y_{1}$} & \multirow[t]{2}{*}{-} & 0.427 & & \\
\hline $\mathbf{X}_{2}$ & & & 0.397 & & \\
\hline $\mathbf{X}_{1}$ & \multirow[t]{3}{*}{$\mathrm{Y}_{2}$} & \multirow[t]{2}{*}{$\mathrm{Y}_{1}$} & 0.052 & $0.427 \times-0.008=-0.0034$ & $0.052-0.0034=0.486$ \\
\hline $\mathbf{X}_{2}$ & & & 0.746 & $0.397 \times-0.008=-0.0032$ & $0.746-0.0032=0.7428$ \\
\hline$Y_{1}$ & & - & -0.008 & & \\
\hline
\end{tabular}

The results showed Table 1 that job stress and organizational climate have a positive and significant effect on employee job satisfaction at STMIK STIE Mikroskil. Showed Table 2 that job stress has no effect on turnover intention, while organizational climate has a positive and significant effect on turnover intention. Job satisfaction has no effect on turnover intention. Meanwhile based on Table 3, the intervening variable, namely job satisfaction, is not able to interview the effect of job stress and 
organizational climate on turnover intention of STMIK STIE Mikroskil employees.

\section{CONCLUSION AND SUGGESTION Conclusion}

The results showed that job stress and organizational climate have a positive and significant effect on employee job satisfaction at STMIK STIE Mikroskil. Job stress has no effect on turnover intention, while organizational climate has a positive and significant effect on turnover intention. Job satisfaction has no effect on turnover intention. Meanwhile, the intervening variable, namely job satisfaction, is not able to interview the effect of job stress and organizational climate on turnover intention of STMIK STIE Mikroskil employees.

\section{Suggestion}

Based on this research, the researcher tries to give the following suggestions:

1. For the Sekolah Tinggi Manajemen Informatika dan Komputer (STMIK) Sekolah Tinggi Ilmu Ekonomi (STIE) Mikroskil Medan City needs to provide trainings regarding procedures and understandings related to work stress. And it is also necessary to organize continuous education for employees to advance human resources in the Sekolah Tinggi Manajemen Informatika dan Komputer (STMIK) Sekolah Tinggi Ilmu Ekonomi (STIE) Mikroskil Medan City.

2. For the Environment of the Sekolah Tinggi Manajemen Informatika dan Komputer (STMIK) Sekolah Tinggi Ilmu Ekonomi (STIE) Mikroskil Medan City needs to improve a comfortable and conducive organizational climate.

3. For further researchers, it is suggested to examine other variables outside of work stress, organizational climate, job satisfaction, turnover intention or to add other research variables such as incentives or promotion.

4. For further research, it is suggested to expand the research population throughout the Sekolah Tinggi Manajemen Informatika dan Komputer (STMIK) Sekolah Tinggi Ilmu Ekonomi (STIE) Mikroskil Medan City so that research results are broader and more accurate on job satisfaction and turnover intention.

Acknowledgement: None

Conflict of Interest: None

Source of Funding: None

\section{REFERENCES}

1. Handoko. (2014). Manajemen Personalia Sumber Daya Manusia. Edisi Kedua. Yogyakarta: BPFE.

2. Kaswan. (2012). Coaching dan Mentoring Untuk Pengembangan SDM dan Peningkatan Kinerja Organisasi. Bandung: Alfabeta.

3. Mobley, W.H. (2012). Pergantian Karyawan: Sebab Akibat dan Pengendaliannya. Jakarta: PT. Pustaka Binaman Perssindo.

4. Mondy R. Wayne. (2010). Manajemen Sumber Daya Manusia. Edisi Kesepuluh. Jakarta: PT Gelora Aksara Pratama.

5. Pencavel, John. (2015). The Productivity of Working Hours. The Economic Journal, Vol. 125, Issue 589.

6. Robbins, \& Judge. (2010). Perilaku Organisasi. Edisi Kesepuluh. Jakarta: PT Index Kompleks Gramedia.

7. Samad, Sarminah. (2014). Predicting Turnover Intentions: The Case of Malaysian Government Doctors. The Journal of American Academy of Business, Cambridge, Vol.8, No.2.

8. Sugiyono. (2016). Metode Penelitian Kuantitatif, Kualitatif dan $\mathrm{R}$ dan $\mathrm{D}$. Bandung: PT Alfabet.

9. Waspodo, Agung AWS. (2013). Pengaruh Kepuasan Kerja dan Stres Kerja terhadap Turnover Intention pada Karyawan PT. Unitex. Bogor: Fakultas Ekonomi Universitas Negeri Jakarta, 
Purnaya Sari Tarigan et.al. Effect of job stress and organizational climate on turnover intention with job satisfaction as an intervening variable for employees of STMIK STIE Mikroskil.

Jurnal Riset Manajemen sains Indonesia. Vol.4, No.1.

10. Winterton, Jonathan. (2014). A Conceptual Model of Labour Turnover and Retention. Human Resource Development International, Vol.7, Pg.371-390.
How to cite this article: Tarigan PS, Ginting $P$, Siahaan E. Effect of job stress and organizational climate on turnover intention with job satisfaction as an intervening variable for employees of STMIK STIE Mikroskil. International Journal of Research and Review. 2021;8(4):468-474. DOI:https://doi.org/10.52403/ijrr.20210456

$* * * * * *$ 